\title{
Abundance and dispersal of Heteronychus arator (Coleoptera: Scarabaeidae) in maize fields under different fertilizer treatments
}

\author{
M. Abdallah, M. W. Mwatawala* and A. B. Kudra
}

*Correspondence:

mwatawala@yahoo.com

Department of Crop Science

and Production, Sokoine

University of Agriculture,

P.O. Box 3005, Morogoro,

Tanzania

\begin{abstract}
The invasive African black beetle Heteronychus arator $F$. is a serious pest of crops in Tropical and sub Tropical regions, including East Africa. Literature on ecology of this pest in Sub Saharan Africa is scarce. Dispersal and abundance of $H$. arator were determined in maize fields in Njombe Region, in the Southern highlands of Tanzania, from December 2013 to May 2014. Adults of H. arator were collected monthly by hand picking and pitfall traps. Results showed that larvae were present throughout the growing season, with low population at planting and peak period coinciding with optimum soil moisture. The abundance of adults varied with time, with high peaks recorded in January. Abundance of both larvae and adults were significantly affected by fertilizer type, with high populations in farmyard manure. The type of fertilizer significantly affected dispersal of H. arator. A high number of beetles moved significantly longer distances in farmyard and inorganic fertilizer compared to bioslurry a day after release. Abundance of of beetles was negatively correlated with rainfall but positively correlated with average temperature, while abundance of larvae was positively correlated with rainfall. The results provide useful input into management of $H$. arator under different fertilizer practices and weather conditions.
\end{abstract}

Keywords: Heteronychus arator, Spatial, Temporal, Fertilizer

\section{Background}

The African black beetle Heteronychus arator F. is a polyphagous insect attacking a wide range of cultivated crops, with a high preference for pastures (King et al. 1981; Matthiessen et al. 1997). Preferred hosts include potato, (Solanum tuberosum L.), Maize (Zea mays L.), pineapple (Ananas comosus (L.) Merr.), and vegetables such as pea (Pisum sativum L.) and tomato (Lycopersicon esculentum Mill) (Venter and Louw 1978; Smith et al. 1995; Sinclair et al. 1997; Toit et al. 1997; Matthiessen and Learmonth 1998). Heteronychus arator originated from South Africa (Venter and Louw 1978), and invaded South America and the Oceania. In Africa, H. arator has been recorded in Eastern and Southern countries, including Namibia, Zambia, Malawi, Mozambique, Botswana, Democratic Republic of Congo and Tanzania.

(c) 2016 Abdallah et al. This article is distributed under the terms of the Creative Commons Attribution 4.0 International License (http://creativecommons.org/licenses/by/4.0/), which permits unrestricted use, distribution, and reproduction in any medium, provided you give appropriate credit to the original author(s) and the source, provide a link to the Creative Commons license, and indicate if changes were made. 
Heteronychus arator attacks various crops during various stages of growth, from seedling to maturity (Ahad and Bhagat 2012). All life stages of $H$. arator are subterranean but adults can fly (King et al. 1981). Young larvae feed on soil organic matter, while more mature larvae attack plant roots. Losses of up to 20-30 \% of sown maize (Drinkwater 1987) and up to $70 \%$ of potato (Venter and Louw 1978; Matthiessen and Learmonth 1995) have been reported. Each adult $H$. arator can attack 2-5 tubers of potato (Matthiessen and Learmonth 1995). It is a pest of phytosanitary significance and it has caused great losses where it has been introduced.

Abundance, dispersal, distribution and damage by $H$. arator are dependent on various ecological factors, including soil temperature, moisture and diseases (King et al. 1981). Temperatures above $15{ }^{\circ} \mathrm{C}$ are most favourable for development and survival of $\mathrm{H}$. arator, with optimum larval development occurring at $20-25{ }^{\circ} \mathrm{C}$ (King et al. 1981). Low temperatures limit larval survival (King and Watson 1982).

Phytophagous insects like $H$. arator are subject to many selective pressures, including the abundance and diversity of plants and their spatial and temporal fluctuations. Knowledge on dispersal and abundance of $H$. arator is limited to the Oceania and South Africa. Quantifying dispersal is key to understanding population dynamics of insects and tracking changes in environmental conditions (Roderick and Caldwell 1992).

Insects' dispersal may be caused by deterioration of habitat, resource depletion, competition or combination of these (Dingle 2001). Likewise, dispersal may be triggered by food availability, population density or environmental factors such as temperature, humidity and rainfall (Danthanarayana 1986). Crops provide a temporal and spatial concentration of resources (Lombaert et al. 2006), which can attract or arrest large number of insects from long distances. A homogeneous crop would provide a high-level of resources to consumers compared to mixed, patchy cropping (Lombaert et al. 2006).

Heteronychus arator is an emerging serious pest of maize in Njombe Region, Tanzania. The pest has not been studied in Tanzania, although farmers have reported high damages. Various control methods have been tested (Ball et al. 1997; Erasmus and Van den Berg 2014; Potter et al. 1996; Koppenhöfer et al. 2000).

Farmers who use farmyard manure and bio slurry in maize fields reported high losses due to $H$. arator in Southern highlands of Tanzania. In this study, it was hypothesized that use of manure and bio slurry increased abundance and dispersal of $H$. arator in maize fields. However, this was not determined by research. To understand factors affecting dispersal and abundance of $H$. arator is important before formulating a sound management program. We studied dispersal spatial and temporal abundance of the beetle in patchy maize fields in Southern highlands of Tanzania in relation to fertilizer application.

\section{Methods}

\section{Description of the study area}

Experiments were conducted in Njombe and Wanging'ombe Districts, Njombe Region in the Southern highlands of Tanzania. Njombe is one of the major maize producing regions of Tanzania. We selected four locations, one in Wanging'ombe and three in Njombe district, based on high incidence of $H$. arator. All the locations are characterized by a uni-modal rainfall pattern, with the rainy season starting from November/ 
December to April/May. The area receives an average annual rainfall of $1500 \mathrm{~mm}$, while the average temperature is $16^{\circ} \mathrm{C}$ per annum. The locations are described in Table 1.

\section{Larval abundance}

The experiment was set in a Randomised Complete Block Design (RCBD) in four locations. The three treatments viz., inorganic fertilizer, bio slurry and farm yard manure (Table 2) were applied in individual plots replicated in three locations. The size of the plot for each treatment was $10 \times 5 \mathrm{~m}\left(50 \mathrm{~m}^{2}\right)$ with $10 \mathrm{~m}$ strips between plots and blocks. The land was prepared in late November and sowing of maize variety PAN 691 (PANNAR Seed Co. Ltd) was done in early December 2013. We established 266 plants $/ 50 \mathrm{~m}^{2}$, at a spacing of $75 \mathrm{~cm} \times 25 \mathrm{~cm}$ giving a population of 53,200 plants/ha. All standard agronomic practices were followed in each location.

Larval abundance was determined from a soil sample extracted around the roots $(20 \times 20 \times 20 \mathrm{~cm})$ of three selected plants in a plot (Ahad and Bhagat 2012). Sampling was done monthly, from December 2013 to May 2014. The larvae in each soil sample were counted and recorded. We recorded mean number of larvae per plot per month.

\section{Adult abundance and dispersal}

Beetles used in this study were collected by hand picking and by trapping every sampling month from January to May. Collection of insects was done in the morning and release was done at night between $700 \mathrm{~h}$ to $900 \mathrm{~h}$ (Nyundo and Yarro 2007).We used plastic pitfall traps $(15 \times 13 \times 8 \mathrm{~cm}$; length, top diameter, bottom diameter $)$, half filled with partially decomposed farmyard manure. Collected insects were kept in semi-transparent plastic boxes $(30 \mathrm{~cm} \times 30.5 \mathrm{~cm} \times 25 \mathrm{~cm})$, filled with farmyard manure, germinated

Table 1 Description of study locations

\begin{tabular}{|c|c|c|c|}
\hline District & Village & Location & Altitude (m a.s.l) \\
\hline Wanging'ombe & Nyumbanitu & 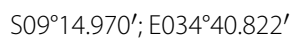 & 1994 \\
\hline \multirow[t]{3}{*}{ Njombe } & Nyombo & $\mathrm{S}^{\circ} 9^{\circ} 3.038^{\prime} ; \mathrm{E}^{\prime} 034^{\circ} 48.845^{\prime}$ & 1809 \\
\hline & Mtwango & S0902.697'; E03448.648' & 1800 \\
\hline & Ibumila & 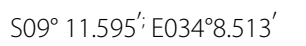 & 1840 \\
\hline
\end{tabular}

Table 2 Fertilizer treatments used in the trial

\begin{tabular}{|c|c|c|c|c|}
\hline Treatment & Fertilizer type & Content & Application rate & Timing of application \\
\hline \multirow[t]{3}{*}{ Inorganic fertilizer } & Yara Mila cereal & $\begin{array}{l}23 \% \mathrm{~N}, 10 \% \mathrm{P}_{2} \mathrm{O}_{5}, 5 \% \\
\mathrm{~K}_{2} \mathrm{O}, 5 \% \mathrm{MgO}, 3 \% \mathrm{~S} \text {, and } \\
0.3 \% \mathrm{Zn}\end{array}$ & 526 kg YMC/ha & At planting \\
\hline & Yara Vera & $46 \% N$ & $40 \mathrm{~kg} \mathrm{~N} / \mathrm{ha}$ & 4 weeks after planting \\
\hline & Yara Mila Java & $23 \% \mathrm{~N}, 6 \% \mathrm{~S}$ & 74 kg YMJ/ha & 12 weeks After planting \\
\hline \multirow[t]{2}{*}{ Bio slurry } & Bio slurry manure & $\begin{array}{l}1.8 \% \mathrm{~N}, 1.5 \% \mathrm{P}_{2} \mathrm{O}_{5}, 1.7 \% \\
\mathrm{~K}_{2} \mathrm{O}\end{array}$ & 8000 kg/ha & At planting \\
\hline & Bio slurry leachate & $\begin{array}{l}1.8 \% \mathrm{~N}, 1.5 \% \mathrm{P}_{2} \mathrm{O}_{5}, 1 \% \\
\mathrm{~K}_{2} \mathrm{O}\end{array}$ & 10,000 L/ha & 4 weeks after planting \\
\hline FYM & Farmyard manure & $\begin{array}{l}0.8 \% \mathrm{~N}, 0.5 \% \mathrm{P}_{2} \mathrm{O}_{5}, 0.7 \% \\
\mathrm{~K}_{2} \mathrm{O}\end{array}$ & 10,000 kg/ha & At planting \\
\hline
\end{tabular}


maize and beans seedlings as food. The elytra of beetles were marked by triangular notching on posterior end one day before the release as suggested by Guzman et al. (2011).

\section{Abundance estimation}

A capture-mark-recapture (CMR) study was conducted during the 2013-2014 cropping season, in uniformly established maize plots within Ibumila village (Table 1). Three plots of $40 \mathrm{~m} \times 45 \mathrm{~m}$ were treated with fertilizers as described in Table 2 and replicated in three locations. Distance between plots was $50 \mathrm{~m}$. A total of 3400 marked beetles were released at each instance for abundance estimation as described by Arakaki et al. (2008). Beetles were released in the night (Nyundo and Yarro 2007) once per month and were recaptured for three consecutive days after each release. Adults were recaptured by hand picking and trapping. Numbers of recaptured beetles were pooled across distance for each plot, each month. We recorded, for each plot, number of released (marked) beetles, number of recaptured beetles and number of unmarked beetles.

Lincoln index was used to determine absolute abundance which is the variation of Jolly-Seber (Bancroft 2005).

$$
\mathrm{N}=\mathrm{M}(\mathrm{U}+1) / \mathrm{R}+1
$$

where $\mathrm{N}$ is the population estimate, $\mathrm{M}$ is the number of marked beetles, $\mathrm{U}$ is the number of unmarked beetles and $\mathrm{R}$ is the number of recapture bugs that were marked. The population estimates depends on the ratio of marked to unmarked beetles that removes bias that might arise due to capture efficiency. To balance the sampling efforts each plot was measured by the total time taken. The effects of distance were corrected by pooling recaptures across distance for each month.

\section{Dispersal estimation}

A total of 1800 marked beetles were released once every month, for dispersal estimation. Release and recapture were done from January to May 2014, as described above. Beetles were recaptured at $2,4,16$, and $32 \mathrm{~m}$ radii from the release point. We recorded and compared the number of beetles caught at each radius from the release point.

\section{Data analysis}

General Linear Model was used to analyse abundance and dispersal of beetles using $R$ statistical package. Two-way analysis of variance (ANOVA) was used to analyse abundance of larvae and beetles, with fertilizer and month as factors. Dispersal was analysed by three factors ANOVA, with as fertilizer type, days after release as the sub factor and distance from release point as factors. Post Hoc Tukey Test was used to compare means. Correlation coefficients for adult and larvae counts with selected weather parameters were calculated using Pearson correlation method under SPSS version 16 and evaluated for significance as suggested by Ahad and Bhagat (2012). 


\section{Results and discussion}

\section{Results}

Temporal variation in larval abundance in maize plots under different fertilizer treatment is presented in Fig. 1. Two way ANOVA results showed that larval abundance was not significantly affected by fertilizer type $\left(\mathrm{F}_{(2,54)}=2.93, \mathrm{p}<0.06\right)$ or month $\mathrm{F}_{(5 \text {, }}$ $54)=2.29, \mathrm{p}<0.058)$. However, the interaction between fertilizer type and month significantly affected abundance of larvae $\left.\mathrm{F}_{(10,554)}=2.88, \mathrm{p}<0.005\right)$. Analysis of simple effects of fertilizers did not show significant variations in larval abundance in December $\left(\mathrm{F}_{(2}\right.$, 9) $=1.48, \mathrm{p}=0.28)$, January $\left(\mathrm{F}_{(2,9)}=1.24, \mathrm{p}=0.33\right)$, February $\left.\mathrm{F}_{(2,9)}=0.57, \mathrm{p}=0.58\right)$ or March $\left.\mathrm{F}_{(2,9)}=1.91, \mathrm{p}=0.2\right)$. Significant simple effects of fertilizers were observed in April $\left.\mathrm{F}_{(2,9)}=10.22, \mathrm{p}=0.004\right)$ and May $\left.\mathrm{F}_{(2,9)}=4.98, \mathrm{p}=0.035\right)$.

Multiple comparison of means (Tukey, $95 \% \mathrm{CI}$ ) showed significant differences between bioslurry and farmyard manure $(\mathrm{p}=0.005)$, as well as bioslurry and inorganic fertilizer $(\mathrm{p}=0.02)$ in April. Farmyard manure and bioslurry were not significantly different ( $\mathrm{p}=0.597$ ). Bioslurry also differed significantly with farmyard manure in May $(\mathrm{p}=0.04)$ but not with inorganic fertilizer $(\mathrm{p}=0.088)$. Farmyard manure and inorganic fertilizer were not significantly different $(\mathrm{p}=0.85)$ in May (See also Fig. 1). Larvae were highly abundant in farmyard manure treated plots, peaking in March and April (Fig. 1).

Figure 2 presents temporal variation in beetles' abundance in maize plots under different fertilizer treatments. The number of collected adults of $H$. arator varied significantly among plots, depending on type of fertilizer $\left(\mathrm{F}_{(2,30)}=9.31, \mathrm{p}<0.001\right)$, and month $\left(\mathrm{F}_{(4 \text {, }}\right.$ 30) $=14.12, \mathrm{p}<0.001)$. The interaction between fertilizer type and month did not significantly affect beetles' abundance $\mathrm{F}_{(8,30)}=1.9, \mathrm{p}=0.09$ ) (see also Fig. 2). Significant main
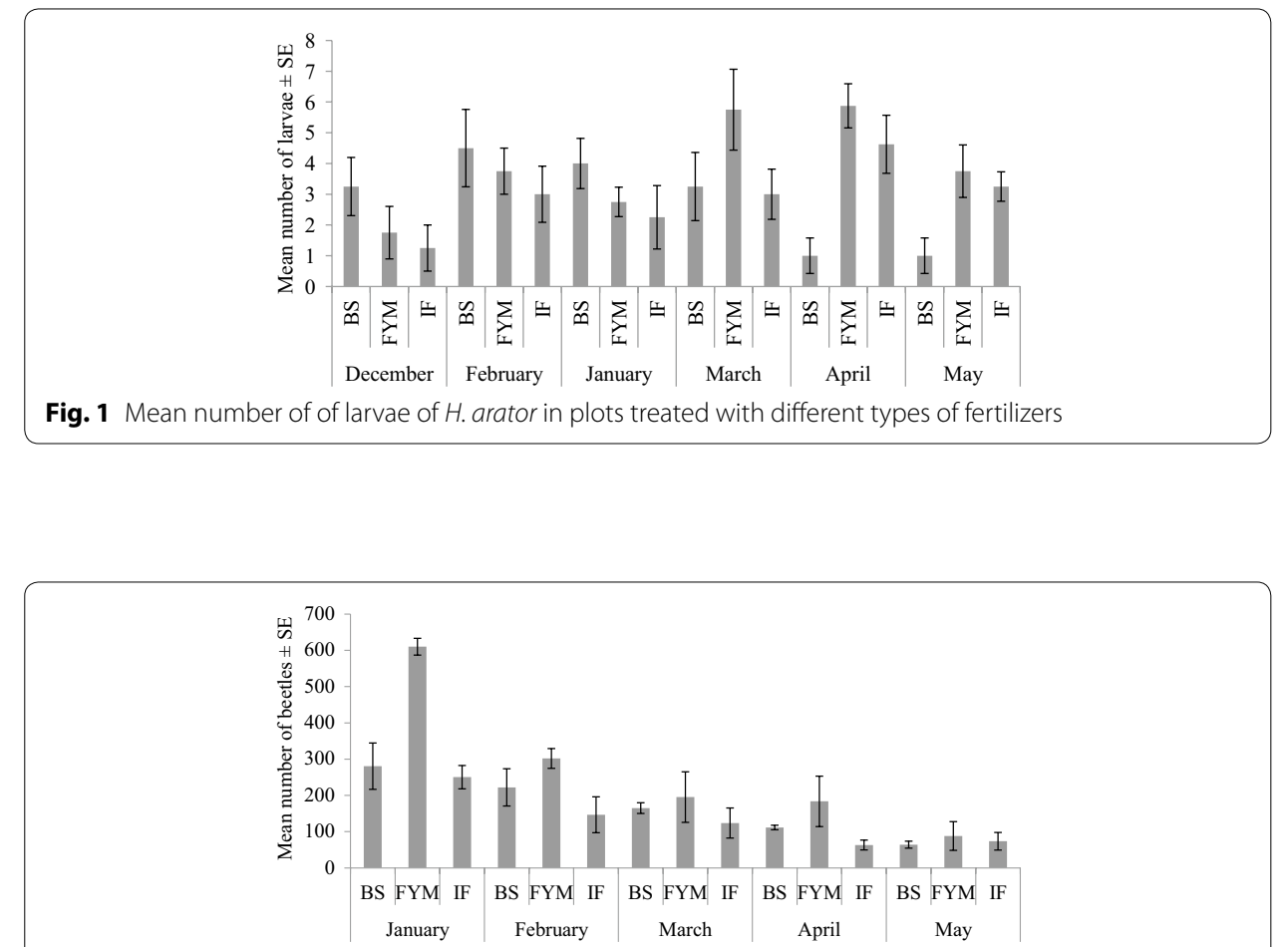

Fig. 2 Mean number of of adults of $H$. arator in plots treated with different types of fertilizers (BS bioslurry, FYM farmyard manure, IF inorganic fertilizer) (BS Bioslurry, FYM farmyard manure, IF inorganic fertilizer) 
effects on beetles' abundance were observed among fertilizers $\left(\mathrm{F}_{(2,6)}=5.66, \mathrm{p}=0.04\right)$ and month $\left(\mathrm{F}_{(4,10)}=10.35, \mathrm{p}=0.001\right)$. Highest marginal mean (fertilizer effects averaged over months) was recorded in farmyard manure (274 \pm 20$)$, followed by bioslurry $(196 \pm 22)$ and inorganic fertilizer $(130 \pm 27)$. Post Hoc Tukey test $(95 \%$ CI) on marginal means revealed significant differences $(\mathrm{p}=0.04)$ in beetles abundance between inorganic fertilizer and farmyard manure, but not between inorganic fertilizer and bioslurry $(\mathrm{p}=0.695)$ or bioslurry and farmyard manure $(\mathrm{p}=0.11)$.

Distance covered by beetles increased with time since release (Fig. 3). Three factors ANOVA results showed that number of recaptured beetles differed significantly with fertilizer type $\left(\mathrm{F}_{(2,90)}=19.22, \mathrm{p}<0.001\right)$, distance from point of release $\left(\mathrm{F}_{(4,90)}=92.82\right.$, $\mathrm{p}<0.001)$ and days since release $\left(\mathrm{F}_{(2,90)}=11.92, \mathrm{p}<0.001\right)$. The interaction between fertilizer, days since release and distance from release point was also significant $\left(\mathrm{F}_{(16 \text {, }}\right.$ $\left.{ }_{90)}=11.92, \mathrm{p}<0.001\right)$. Analysis further showed significant simple interactions between fertilizer and distance from release point, after day $\left.1 \mathrm{~F}_{(2,30)}=32.5\right)$, day $2 \mathrm{~F}_{(2,30)}=24.98$, $\mathrm{p}=0.001)$, and day $3\left(\mathrm{~F}_{(2,30)}=5.51, \mathrm{p}=0.001\right)$ since release. Post hoc Tukey test $(95 \%$ CIs) showed that significantly less numbers of beetles were caught in bioslurry plots at longer distances from release point day after release. Significantly more beetles were
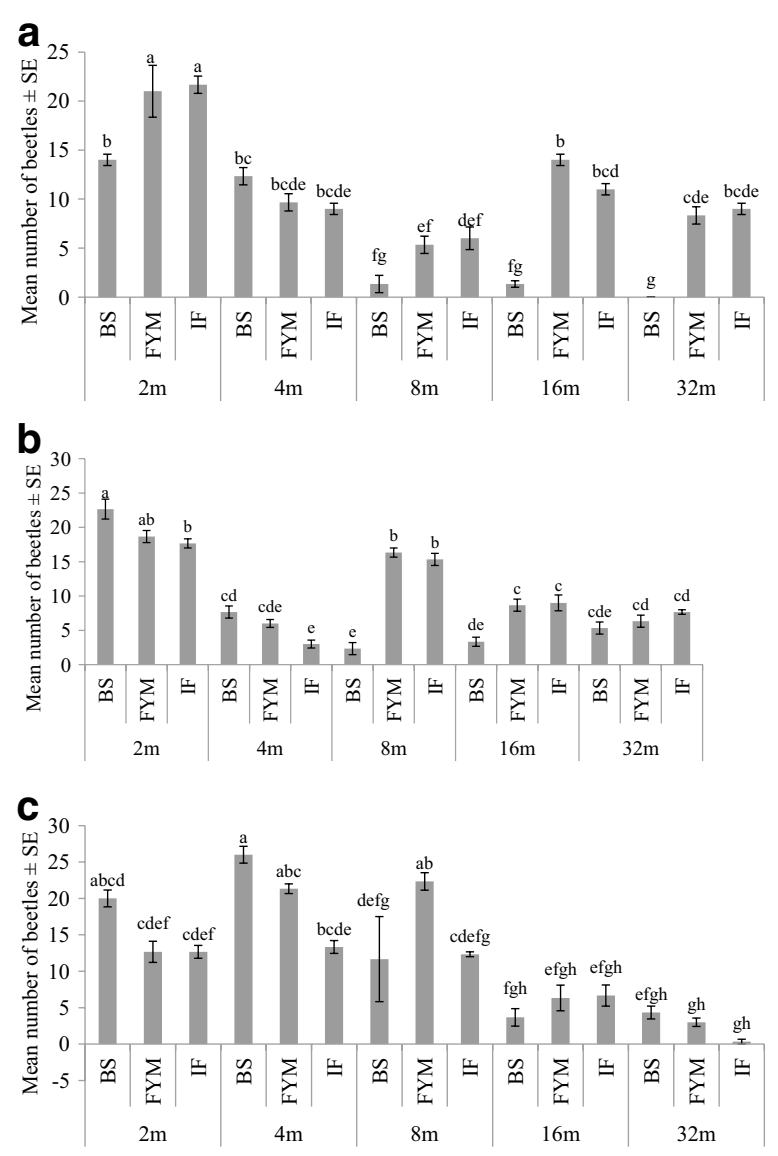

Fig. 3 Mean number of beetles caught at various distances from release point in plots under different fertilizer treatments $\mathbf{a}$ a day after release $\mathbf{b} 2$ days after release $\mathbf{c} 3$ days after release. (BS bioslurry, FYM farmyard manure, IF inorganic fertilizer). Mean with the same letters are not significantly different (Tukey test, $95 \%$ Cl) 
caught within the release point in farmyard manure and inorganic fertilizer plots, a day after release (Fig. 3).

Poisson regression results showed significant associations between rainfall, average temperature and adults abundance (Table 3). The number of beetles significantly decreased with increase in rainfall $(\mathrm{e}=-0.011, \mathrm{p}<0.001, \operatorname{Exp}[\beta]=0.989)$. On the contrary, average temperature was positively associated with number of beetles $[e=0.748$, $\mathrm{p}<0.001, \operatorname{Exp}(\beta)=2.11$ ]. Relative humidity had no significant effect on beetles' abundance (Table 3). Larval abundance was significantly associated with rainfall $[e=0.0045$, $\mathrm{p}<0.03$, Exp $(\beta)=1.004]$, but not with relative humidity and average temperature (Table 4).

\section{Discussion}

This study presents the abundance and dispersal of the invasive $H$. arator in soils under different fertilizer management. Our results revealed dependence of larval and beetles' abundance on fertilizer type. We also observed temporal variations in larval and beetles abundance, with high numbers in farmyard manure treated plots. Sara et al. (2013) suggested that spatial activities of beetles are greatly influenced by change in habitat. Adults and white grubs of green jute beetle were reported to be attracted to the field fertilized with farmyard manure from cow and poultry (Diagne 2004).

Dispersal of $H$. arator from the release point increased with time. Schumann and Vidal (2012) reported that dispersal of the Western Corn Borer larvae increased as they developed and the larvae moved off their original place of emergence and into deeper soil layers. Ross and Ostlie (1990) reported mean dispersal distance Ostrinia nubilalis (Hübner) increased linearly with time. Glogoza et al. (1998) observed a positive association between the probability of finding Phyllophaga implicita (Horn) (Coleoptera: Scarabaeidae) and the distance from the food source.

Results from the current study showed that temperature, and rainfall played a major role on temporal abundance of $H$. arator. Ahad and Bhagat (2012) reported that the population of larvae (white grubs) is determined by rainfall and soil moisture. East et al.

Table 3 Correlation between number of adults and weather parameters

\begin{tabular}{lccccc}
\hline Parameter & e & SE & t (*) & Tpr & Exp ( $\beta)$ \\
\hline RH & 0.367 & 0.204 & 1.80 & 0.072 & 1.444 \\
Rainfall & -0.01112 & 0.00218 & -5.10 & $<.001$ & 0.9889 \\
Av temperature & 0.748 & 0.166 & 4.50 & $<.001$ & 2.112 \\
\hline
\end{tabular}

e coefficient of parameters, $S E$ standard error of estimates, $t\left(^{*}\right)$ standard error, tpr probability, Exp ( $\beta$ ) exponent of estimate

Table 4 Correlation between number of larvae and weather parameters

\begin{tabular}{llllll}
\hline Parameter & e & SE & $\mathbf{t}\left(^{*}\right)$ & Tpr & Exp ( $\boldsymbol{\beta})$ \\
\hline RH & 0.577 & 0.368 & 1.57 & 0.117 & 1.780 \\
Rainfall & 0.00449 & 0.00207 & 2.17 & 0.030 & 1.004 \\
Av temperature & 0.029 & 0.100 & 0.29 & 0.773 & 1.029 \\
\hline
\end{tabular}

e coefficient of parameters, SE standard error of estimates, $t\left({ }^{*}\right)$ standard error, tpr probability, Exp ( $\beta$ ) exponent of estimate 
(1981) reported that black maize beetle was a persistent problem during favourable environmental conditions such as rainfall, temperature, relative humidity and good soil types. Soil moisture also plays a significant role in burrowing depth of $H$. arator, with deeper burrows associated with high level of soil moisture. Further, both organic matter and soil moisture were reported to influence the selection of habitat for burrowing and oviposition by many beetles (Diagne 2004).

The abundance of adults was positively correlated with temperature, but negatively, correlated with rainfall. On other hand, the abundance for larvae was positively correlated with rainfall but not temperature and relative humidity. Temperature may be a key driver for spatial and temporal abundance of arthropods (Kearns and Stevenson 2012). Survival and growth rate of $H$. arator are favoured by high temperature and rainfall, as most physiological responses could be triggered by the change in temperature (King and Watson 1982). The influence of temperature on population dynamics of H.arator might be modified by other factors such as soil types, level of soil moisture, crop composition and management practices (East et al. 1981).

According to East et al. (1981) H. arator adults can undergo extensive dispersal flights due to high mobility imposed for oviposition during dry season. Diagne (2004) pointed out that during the periods of mating the adults tend to avoid hard soils with little organic matter content and concentrate in areas with soft soils which are rich in organic matter, and this biological behaviour has influence on the extent of beetles dispersal. Early flights appear to be initiated by the first rainfall, as adults emerge from pupae (Bell et al. 2011).

\section{Conclusion}

This study provided the basic information for $H$. arator on maize, in trials done in one season cycle. Abundance of black maize beetle is dependent on type of fertilizer as well as climatic factors, notably rainfall, relative humidity and temperature. Timely application of fertilizer is necessary to ensure growth of strong plants that can withstand attacks by the pest. Future multi seasonal studies are recommended.

Authors' contributions

AM carried out the experiments in the field, and he collected and analyzed data and prepared the draft manuscript. MM conceived, designed and supervised the experiments. AK supervised the work in the field and participated in data analysis. All authors read and approved the final manuscript.

\section{Acknowledgements}

We are grateful to Conservation Agriculture project funded by Enhancing Pro-poor Innovation in Natural Resources and Agricultural Value Chains (EPINAV) program. We are indebted to the Innovative Agricultural Research Initiative (iAGRI) for funding my studies and this research through training and personal communication.

\section{Competing interests}

We, the authors declare that we have no competing interests.

Received: 21 September 2015 Accepted: 15 February 2016

Published online: 25 February 2016

\section{References}

Ahad I, Bhagat RM (2012) Incidence and distribution of coleopteran insect pests on rainfed maize (Zea mays L.) in upper Himalayas of Jammu and Kashmir, India. J Phytol 3(11):9-12

Arakaki NA, Agayama AN, Obayashi AK, Arora KT, Ishita MK, Adoyama YS, Ougi NM (2008) Estimation of abundance and dispersal distance of the sugarcane click beetle Melanotus sakishimensis Ohira (Coleoptera: Elateridae) on Kurima Island, Okinawa by mark-recapture experiments. J Appl Entomol Zool 43(3):409-419 
Ball OJP, Miles CO, Prestidge RA (1997) Ergopeptine alkaloids and Neotyphodium lolii-mediated resistance in perennial ryegrass against adult Heteronychus arator (Coleoptera: Scarabaeidae). J Econ Entomol 90(1):1382-1391

Bancroft JS (2005) Dispersal and abundance of Lygus hesperus in field crops. Environ Entomol 34(6):1517-1523

Bell NL, Townsend RJ, Popay AJ, Mercer CF, Jackson TA (2011) Black beetle: lessons from the past and options for the future. Grassl Res Pract Ser 15:119-124

Danthanarayana W (1986) Insect flight_-dispersal and migration. Springer, Berlin

Diagne A (2004) Seasonal occurrence of Phyllophaga species and biological studies of Phyllophaga ephilida (Say) on sweet potato, Ipomoea batatas (L.) Lam, in Louisiana. A Ph.D. Dissertation, Agricultural and Mechanical College, Louisiana State University, Louisiana, USA

Dingle H (2001) The evolution of migratory syndromes in insects. In: Woiwood LP, Reynolds DR, Thomas CD (eds) Insect movement: mechanisms and consequences. CABI, Wallingford, pp 159-181

Drinkwater TW (1987) The efficacy of inseticides in the control of the Black maize beetle Heteronychus arator (Col: Scarabaedae) in Maize black beetle in South Africa. Phytophyl 19:275-277

East R, King PD, Watson RN (1981) Population studies of grass grub (Costelytra zealandica) and Black beetle (Heteronychus arator) (Coleoptera: Scarabaeidae). N Z J Ecol 4:56-64

Erasmus A, Van den Berg J (2014) Effect of Bt-Maize Expressing Cry1Ab toxin on non-target Coleoptera and Lepidoptera pests of maize in South Africa. Afr Entomol 22(1):167-179

Glogoza PA, Weiss MJ, Rao MB (1998) Spatial distribution of Phyllophaga implicita (Horn) (Coleoptera: Scarabaeidae) larvae in relation to distance from the adult food source. J Econ Entomol 91(2):457-463

Guzman LI, Frake AM, Rinderer TE (2011) Marking small hive beetles with thoracic notching: effects on longevity, flight ability and fecundity. Apidol 43(4):425-431

Kearns P, Stevenson RD (2012) Effect of decreasing temperature on Arthropod diversity and abundance in horse dung decomposition communities of South-Eastern Massachusetts. Psyche 2012:1-12

King PD, Watson RN (1982) Prediction and monitoring of black beetle, Heteronychus arator (Coleoptera:Scarabaeidae), outbreaks in New Zealand. N Z Entomol 7(3):54-67

King PD, Mercer CF, Meekings JS (1981) Ecology of black beetle Heteronychus arator (Coleoptera: Scarabaidae)—population studies. N Z Agric Res 24(1):87-89

Koppenhöfer AM, Wilson M, Brown I, Kaya HK, Gaugler R (2000) Biological control agents for white grubs (Coleoptera: Scarabaeidae) in anticipation of the establishment of the Japanese beetle in California. J Econ Entomol 93:71-87

Lombaert E, Boll R, Lapchin L (2006) Dispersal strategies of phytophagous insects at a local scale: adaptive potential of aphids in an agricultural environment. Evol Biol 6:75

Matthiessen JN, Learmonth SE (1995) Impact of the soil insects African black beetle, Heteronychus arator (Coleoptera: Scarabaeidae) and white fringed weevil, Graphognathus leucoloma (Coleoptera: Curculionidae), on potatoes and effects of soil insecticide treatments in south-western Australia. Bull Entomol Res 85(1):101-111

Matthiessen JN, Learmonth SE (1998) Seasonally contrasting activity of African black beetle, Heteronychus arator (Coleoptera: Scarabaeidae): implications for populations, pest status and management. Bull Entomol Res 88:443-450

Matthiessen JN, Learmonth SE, Sumner MW, Allsopp PG, Rogers DJ, Robertson LN (1997) Surface activity of African black beetle in spring favours a pre-oviposition adulticide approach to its management. In: Allsopp PG, Rogerds DJ, Robertson, LN (eds) Proceedings of the 3rd Brisbane soil invertebrates workshop, Bureau of Sugar Experimental Stations, Brisbane, pp 149-152

Nyundo BA, Yarro JG (2007) An assessment of methods for sampling carabid beetles (Coleptera: carabidae) in a mountain rain forest. Tanzan J Health Res 33:41-49

Potter DA, Powell AJ, Spicer PG, Williams DW (1996) Cultural practices affect root-feeding white grubs (Coleoptera: Scarabaeidae) in turfarass. J Econ Entomol 89:156-164

Roderick G, Caldwell R (1992) An entomological perspective on animal dispersal. In: Stenseth N, Lidicke W (eds) Animal dispersal: small mammals as a model. Chapman and Hall, London, pp 274-290

Ross SE, Ostlie K (1990) Dispersal and survival of early instars of European corn borer (Lepidoptera: Pyralidae) in field corn. J Econ Entomol 83(3):831-836

Sara SA, McCallen EB, Switzer PV (2013) The spatial distribution of the Japanese beetle, Popillia japonica, in soybean fields. J Insect Sci 13(36):36-42

Schumann M, Vidal S (2012) Dispersal and spatial distribution of western corn rootworm larvae in relation to root phenology. Agric For Entomol 14(4):331-339

Sinclair E, Scott C, Allsopp PG, Rogers DJ, Robertson LN (1997) Soil invertebrates in the Queensland pineapple industry. In: Allsopp PG, Rogerds DJ, Robertson, LN (eds) Proceedings of the 3rd Brisbane workshop on soil invertebrates, Bureau oof Sugar Experimental Stations, Brisbane, pp 134-137

Smith TJ, Petty GJ, Villet MH (1995) Description and identification of white grubs (Coleoptera: Scarabaeidae) that attack pineapple crops in South Africa. Afr Entomol 3:153-166

Toit HD, Allsopp PG, Rogers DJ, Robertson LN (1997) Habitat preference of African black beetle and other soil insect pests of maize in South Africa. In: Allsopp PG, Rogerds DJ, Robertson, LN (eds) Proceedings of the 3rd Brisbane soil invertebrates workshop, Bureau of Sugar Experimental Stations, Brisbane, pp 44-47

Venter RJH, Louw M (1978) Heteronychus arator (Fabricius), a potential dangerous pest on potatoes (Coleoptera: Scarabeidae). Phytophyl 10:99-105 